PERcursos Linguísticos • Vitória (ES) •v. 10 •n. 25 • 2020 • ISSN: 2236-2592 • Dossiê:

Discursos de resistência e corpos (re)existentes •

\title{
Palavra dos Editores
}

É com grande satisfação que anunciamos a publicação de mais um volume temático da Revista PERcursos Linguísticos, reafirmando, assim, o compromisso do periódico em tornar visível a ampla variedade de investigações possíveis dentro do complexo fenômeno da linguagem. No presente volume, temos a satisfação de apresentar uma coleção de importantes artigos organizados por Luciane de Paula, Luciano Vidon e Maria da Penha Casado Alves. Dos diversos 52 trabalhos submetidos, 28 artigos foram avaliados criteriosamente e selecionados para compor o dossiê Discursos de resistência e corpos (re)existentes (Vol. 10, N. 25, 2020). Os trabalhos que fazem parte do volume trazem importantes discussões, em diferentes áreas dos Estudos do Discurso, contribuindo com reflexões teóricas ou analíticas acerca da temática da resistência e do corpo. De tal modo, investigadores de diversas universidades e sobre diferentes perspectivas discursivas, como a Análise Crítica do Discurso, a Análise do Discurso de linha francesa, a Análise Dialógica do Discurso, a Semiótica etc., contribuíram, em grande medida, para ampliar as discussões sobre os corpos, as tentativas de silenciamento e os modos de resistência que travam batalhas na arena discursiva. Esperamos, de tal modo, que este dossiê seja uma referência para os interessados no escopo mencionado. Aproveitamos e agradecemos aos autores pela generosidade em compartilhar os trabalhos e aos organizadores pela disposição, parceria e contribuição. Desejamos uma excelente leitura a todos!

Vitória, Espírito Santo, outubro de 2019 Patrick Rezende Guilherme Brambila

Editores 